\title{
Delisheng induces antiproliferation and apoptosis effects in Hep3B cells via modulation of angiogenic proteins
}

\author{
HAI-FENG SUN ${ }^{1,2}$, LI JING ${ }^{1}$, TAO WU ${ }^{1}$, MING LI $^{2}$, YA-HUAN GUO ${ }^{2}$, HUI GUO ${ }^{1}$, \\ ZHENG ZHAO $^{2}$, MIN-CONG WANG ${ }^{1}$, SHU-HONG WANG ${ }^{1}$ and KE-JUN NAN ${ }^{1}$ \\ ${ }^{1}$ Department of Medical Oncology, The First Affiliated Hospital of Xi'an Jiaotong University; \\ ${ }^{2}$ Department of Medical Oncology, Tumor Hospital of Shaanxi Province, Xi'an, Shaanxi 710061, P.R. China
}

Received November 10, 2015; Accepted April 13, 2017

DOI: 10.3892/ol.2017.7074

\begin{abstract}
Delisheng is a widely used antineoplastic agent in China. Although previous studies revealed that Delisheng exhibits numerous pharmacological effects including the inhibition of cancer cell differentiation and enhancement of immune function with the lowest toxicity, the precise anticancer mechanisms of Delisheng in human hepatocellular carcinoma (HCC) cells remains largely unknown. The present study investigated the potential mechanisms underlying the anticancer properties of Delisheng on Hep3B cells. Delisheng demonstrated a strong anti-proliferation effect on Hep3B cells compared with normal liver HL-7702 cells, as detected by MTT assays. In addition, Delisheng arrested the cells in $\mathrm{G} / \mathrm{G}_{1}$ phase. Furthermore, it exhibited a pro-apoptotic effect on Hep3B cells, as detected by flow cytometry. When exposed to Delisheng, Hep3B cells demonstrated decreased vascular endothelial growth factor (VEGF) and osteopontin (OPN) and increased endostatin (ES) protein expressions, as detected using immunocytochemistry staining and western blotting. These data suggest that Delisheng induces antiproliferation and apoptosis of Hep3B cells via modulation of VEGF, OPN and ES protein expression. It is hypothesized that Delisheng may be used as a novel anticancer therapeutic in HCC.
\end{abstract}

\section{Introduction}

Hepatocellular carcinoma (HCC) is an aggressive neoplasm with an increasing incidence, representing the fifth most common cancer globally (1). It is also the third leading cause of cancer-associated mortality (2). Surgical resection is the cornerstone of therapeutic strategy in the early stages of

Correspondence to: Dr Ke-Jun Nan, Department of Medical Oncology, The First Affiliated Hospital of Xi'an Jiaotong University, 277 Yanta West Road, Xi'an, Shaanxi 710061, P.R. China E-mail: 15929912907@163.com

Key words: angiogenic proteins, Delisheng, antiproliferation, apoptosis, Hep3B cells
HCC. However, numerous patients with HCC with advanced or distant metastatic disease are not candidates for these therapies (3). HCC is well characterized as demonstrating an inherently chemotherapy-refractory nature, and systemic cytotoxic chemotherapy agents exhibit minimal effectiveness on improving patient survival $(4,5)$. Therefore, exploring novel anticancer agents that are more effective for $\mathrm{HCC}$ is important. A number of traditional Chinese medicines, with wide use in clinical practice in China, have been the source of novel anticancer drug developments (6-10). Delisheng, a Chinese medicinal compound that consists of ginseng, milk vetch root, bufonis secretions and cantharidium (11), has previously attracted attention (11), but the potential molecular mechanisms underlying its anticancer effect are unknown.

During carcinogenesis, angiogenesis exhibits a key role in regulating physiological functions (12). This process is characterized by decreasing levels of antiangiogenic proteins and increasing levels of factors that stimulate vasculogenesis (13). Despite previous studies demonstrating that vascular endothelial growth factor(VEGF), osteopontin (OPN) and endostatin (ES) are involved in tumor angiogenesis $(14,15)$, their association with HCC is poorly understood.

In the present study, human hepatocarcinoma Hep3B cells and normal liver HL-7702 cells were utilized to further study the underlying mechanisms of the anticancer effects of Delisheng. It was demonstrated that Delisheng exhibits anti-proliferative and pro-apoptotic effects on Hep3B cells, and that the angiogenic proteins VEGF, OPN and ES are involved in this process.

\section{Materials and methods}

Cell culture. The human hepatocarcinoma Hep3B and normal liver HL-7702 cell lines were purchased from Chinese Academy of Sciences Institute of Life Sciences Cell Resource Center (Shanghai, China). They were grown in RPMI-1640 medium and Dulbecco's modified Eagle's medium (DMEM; GE Healthcare Life Sciences; Hyclone, Logan, UT, USA), respectively. The cell cultures contain 10\% fetal bovine serum (GE Healthcare Life Sciences; Hyclone) and $100 \mathrm{U} / \mathrm{ml}$ penicillin and streptomycin (Gibco; Thermo Fisher Scientific, Waltham, MA, USA) at $37^{\circ} \mathrm{C}$ with $5 \% \mathrm{CO}_{2}$. Then, cells were harvested in the logarithmic growth phase for subsequent experiments. 
Table I. Delisheng inhibits the proliferation of Hep3B and HL-7702 cell lines.

\begin{tabular}{lccccr}
\hline & & \multicolumn{3}{c}{ Inhibition rate, $\%$} \\
\cline { 3 - 4 } Cells & Concentration, $\mu 1 / \mathrm{ml}$ & $24 \mathrm{~h}$ & $48 \mathrm{~h}$ & $72 \mathrm{~h}$ & P-value \\
\hline Hep3B & 25 & $24.62 \pm 4.31^{\mathrm{a}}$ & $36.17 \pm 9.24^{\mathrm{a}}$ & $47.14 \pm 7.48^{\mathrm{a}}$ & 0.037 \\
& 50 & $39.13 \pm 3.52^{\mathrm{b}}$ & $48.94 \pm 6.65^{\mathrm{b}}$ & $59.69 \pm 5.26^{\mathrm{b}}$ & 0.021 \\
& 100 & $57.73 \pm 5.13^{\mathrm{c}}$ & $69.72 \pm 6.42^{\mathrm{c}}$ & $85.92 \pm 4.19^{\mathrm{c}}$ & 0.003 \\
HL-7702 & 25 & $10.41 \pm 3.06^{\mathrm{d}}$ & $12.15 \pm 3.15^{\mathrm{d}}$ & $16.94 \pm 2.53^{\mathrm{d}}$ & 0.216 \\
& 50 & $14.85 \pm 6.12^{\mathrm{e}}$ & $19.32 \pm 6.14^{\mathrm{e}}$ & $24.39 \pm 6.31^{\mathrm{e}}$ & 0.125 \\
& 100 & $23.14 \pm 4.02^{\mathrm{f}}$ & $25.24 \pm 4.63^{\mathrm{f}}$ & $26.09 \pm 3.18^{\mathrm{f}}$ & 0.766 \\
\hline
\end{tabular}

${ }^{\mathrm{a}} \mathrm{P}<0.05$, compared with $\mathrm{d}$; ${ }^{\mathrm{b}} \mathrm{P}<0.05$, compared with $\mathrm{e}$; ${ }^{\mathrm{c}} \mathrm{P}<0.05$, compared with $\mathrm{f}$. Data are presented as the mean \pm standard deviation.

MTT assays. Hep3B cells $\left(2 \times 10^{5}\right.$ cells) and the normal liver HL-7702 cell ( $2 \times 10^{5}$ cells) suspended in $150 \mu 1$ DMEM and RPMI-1640 medium with 10\% FBS, respectively. They were seeded into each well of 96-well microtiter plates overnight, and then treated with 25, 50 and $100 \mu \mathrm{l} / \mathrm{ml}$ Delisheng. Cells were cultured at $37^{\circ} \mathrm{C}$ and $5 \% \mathrm{CO}_{2}$ for 24,48 and $72 \mathrm{~h}$ at each concentration of Delisheng. Subsequently, $20 \mu 1 \mathrm{MTT}$ $(5 \mathrm{mg} / \mathrm{ml})$ was added to each well for $4 \mathrm{~h}$ at $37^{\circ} \mathrm{C}$ and formazan crystals were dissolved in $200 \mu 1$ dimethyl sulfoxide for each well. The optical density (OD) value was recorded at a wavelength of $492 \mathrm{~nm}$. The rate of growth inhibition $(\%)=(1-$ OD of treated group) / (OD of control) x 100. This experiment was repeated in triplicate.

Cell-cycle analysis. The Hep3Bcells treated with Delisheng ( $2 \times 10^{5}$ cells/group) were trypsinized, washed twice with cold PBS and harvested by centrifugation at $4,000 \mathrm{xg}$ and $37^{\circ} \mathrm{C}$ for $5 \mathrm{~min}$, and then incubated in $100 \mu \mathrm{g} / \mathrm{ml}$ propidium iodide (PI) with RNaseA $(5 \mu \mathrm{g} / \mathrm{ml})$ following fixation with $70 \%$ ice-cold ethanol at room temperature (RT) for $30 \mathrm{~min}$. Cellular DNA content was subsequently analyzed by flow cytometry analysis on a BD FACSCalibur system (BD Biosciences, Franklin Lakes, NJ, USA), as previously described (16).

Cell apoptosis assay. Hep3B and HL-7702 cells treated with 25,50 and $100 \mu \mathrm{l} / \mathrm{ml}$ Delisheng were collected and washed twice with cold PBS, and centrifuged at 5,000 $\mathrm{x}$ g for 5 min, followed by staining with $5 \mu 1$ Annexin V-fluorescein isothiocyanate and $5 \mu \mathrm{l} \mathrm{PI}$ for $15 \mathrm{~min}$ at $37^{\circ} \mathrm{C}$ in darkness. The apoptotic cells were subsequently analyzed by fluorescence-activated cell sorting (FACSCalibur; BD Biosciences) using Cell Quest Research 3.3 Software (BD Biosciences).

Immunocytochemistry staining. This procedure has been described previously (15). Briefly, following treatment with $25 \mu \mathrm{l} / \mathrm{ml}$ Delisheng, the Hep3B cells were washed with PBS and then stained with the primary antibodies (Beijing Zhongshan Golden Bridge Biotechnology Co., Ltd. Beijing, China) against VEGF (cat.no.,ZA-0509), OPN (cat. no., ZM-0174) and ES (cat. no., TA507124) (dilutions, 1:100) overnight at $4^{\circ} \mathrm{C}$. The next day, the cells were washed with PBS 3 times, followed by incubation with a secondary antibody (Biotinylated goat anti-rabbit IgG; cat. no., bs-0294P; Xiamen Bosen Biotechnology Co.
Table II. Change in cell cycle distribution of Hep3B cells treated with Delisheng.

\begin{tabular}{lccc}
\hline & \multicolumn{3}{c}{ Cell cycles } \\
\cline { 2 - 4 } $\begin{array}{l}\text { Concentration, } \\
\mu \mathrm{l} / \mathrm{ml}\end{array}$ & $\mathrm{G}_{0} / \mathrm{G}_{1}$ cycle & S cycle & $\mathrm{G}_{2} /$ Mcycle \\
\hline 0 & $19.90 \pm 2.57$ & $69.05 \pm 4.83$ & $11.06 \pm 3.22$ \\
25 & $39.36 \pm 5.41^{\mathrm{a}}$ & $37.70 \pm 4.16$ & $22.94 \pm 4.79$ \\
50 & $50.75 \pm 5.82^{\mathrm{a}}$ & $30.72 \pm 3.73$ & $18.53 \pm 4.63$ \\
100 & $61.06 \pm 4.58^{\mathrm{a}}$ & $22.26 \pm 3.84$ & $16.68 \pm 3.98$ \\
\hline
\end{tabular}

${ }^{\mathrm{a}} \mathrm{P}<0.05$ compared with the control cells. Data are presented as the mean \pm standard deviation.

Ltd., Xiamen, China) diluted to $1: 500$ for $20 \mathrm{~min}$ at $37^{\circ} \mathrm{C}$, and then immunostained using an avidin-biotin complex (ABC) protocol (ABC Staining Kits; Xiamen Bosen Biotechnology Co., Ltd. Xiamen, China) for $30 \mathrm{~min}$, according to the protocol of the manufacturer. The color reaction was visualized through a light microscope (Olympus BH-12, Tokyo, Japan) at magnification, $x 400$ using 3,3'-diaminobenzidinefor $5 \mathrm{~min}$. The nuclei were counterstained with hematoxylin $(10 \mathrm{mg} / \mathrm{ml})$ solution (Beyotime Institute of Biotechnology, Shanghai, China) at $37^{\circ} \mathrm{C}$ for $10 \mathrm{sec}$.

Evaluation of immunocytochemistry staining. The immunoreactivity was evaluated according to the cell staining degree and percentage rate of the positive cell. Staining intensity was graded as follows: 0, no staining; 1 , weak; 2, moderate; and 3, strong. The percentage of positively stained cells was scored as follows: $0, \leq 5 \% ; 1,5-25 \% ; 2,26-50 \%$; and $3,>50 \%$. The score of staining intensity and percentage score of positive cells were multiplied. In these groups, tumors with 0-2 scores were noted as negative, while 3-9 scores were designated as positive. The immunocytochemical results were quantitatively analyzed using LeicaQ550cw imaging analysis system (Leica Microsystems GmbH, Wetzlar, Germany).

Western blotting. Following treatment with $25 \mu \mathrm{l} / \mathrm{ml}$ Delisheng, the Hep3B cells were harvested in ice-cold PBS and lysed with 
A
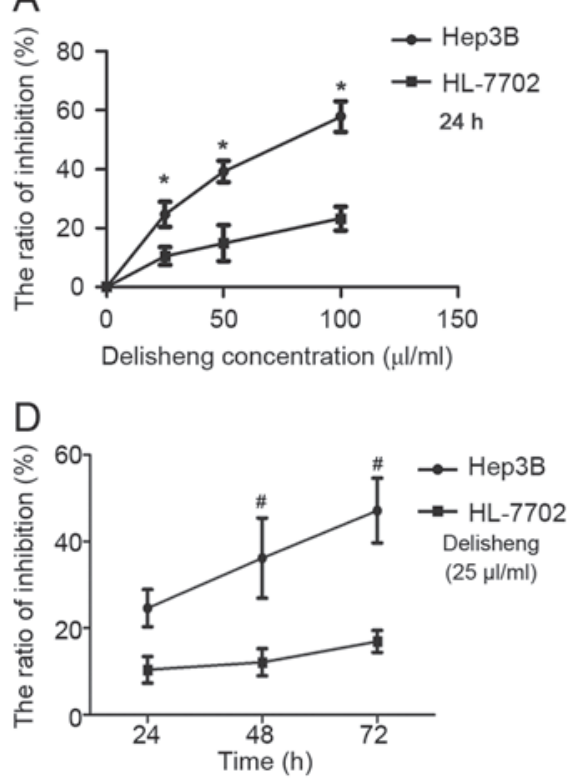

$\mathrm{B}$
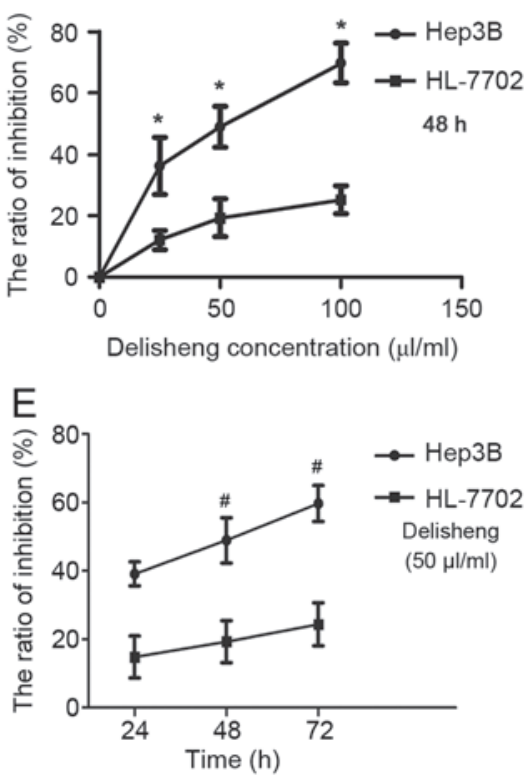

C

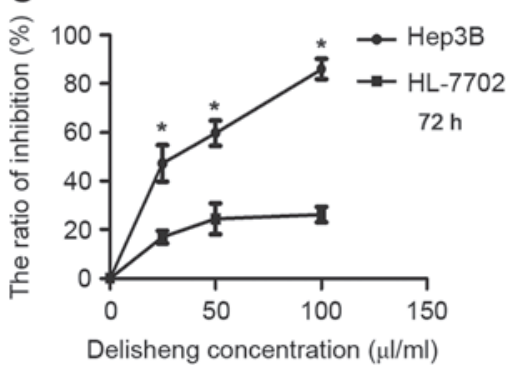

$\mathrm{F}$

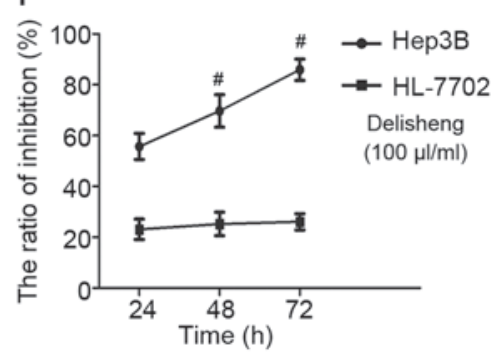

Figure 1. Delisheng inhibits proliferation in Hep3B and HL-7702 cells. Cells treated with Delisheng for (A) $24 \mathrm{~h}$, (B) $48 \mathrm{~h}$ and (C) $72 \mathrm{~h}$, (D) $25 \mu 1 / \mathrm{ml}$, (E) $50 \mu 1 / \mathrm{ml}$, (F) $100 \mu \mathrm{l} / \mathrm{ml}$. Data summarized as the mean \pm standard deviation from 3 independent experiments. ${ }^{~} \mathrm{P}<0.05 \mathrm{vs}$. control (HL-7702 cells), ${ }^{\prime \prime} \mathrm{P}<0.05 \mathrm{vs} .24 \mathrm{~h}$.
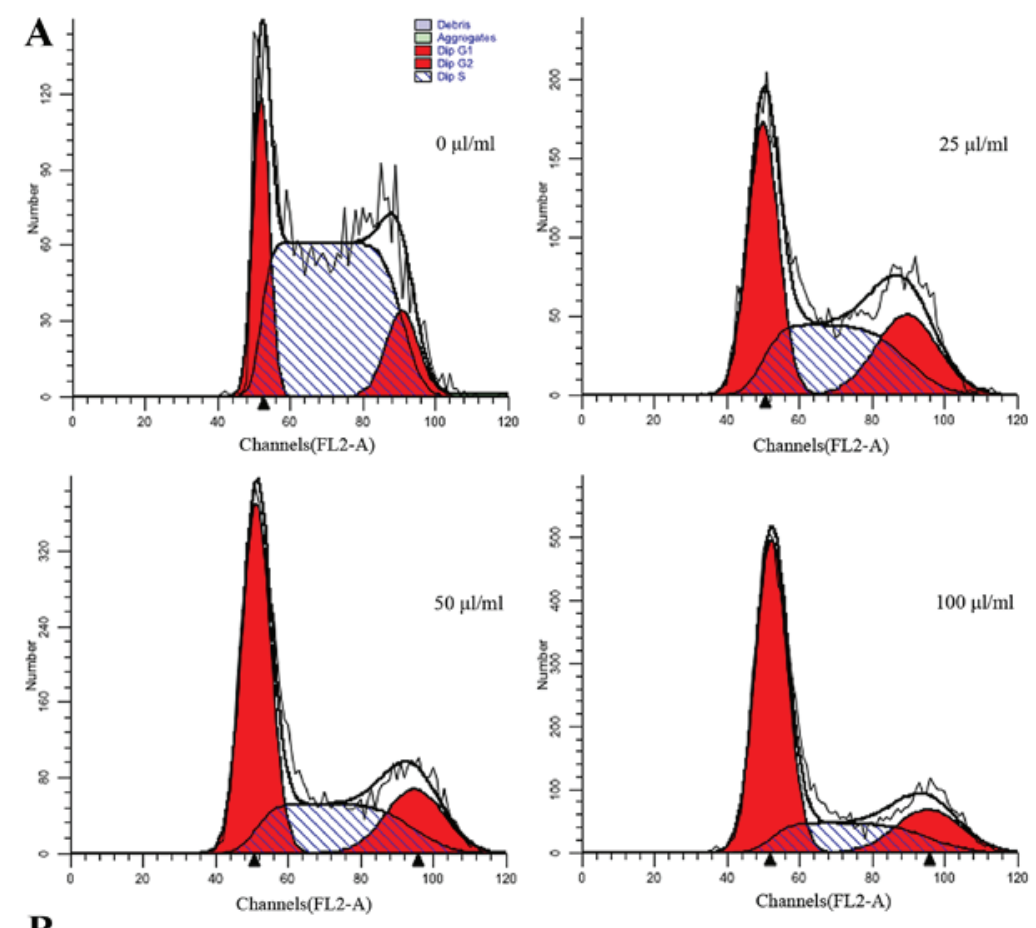

B

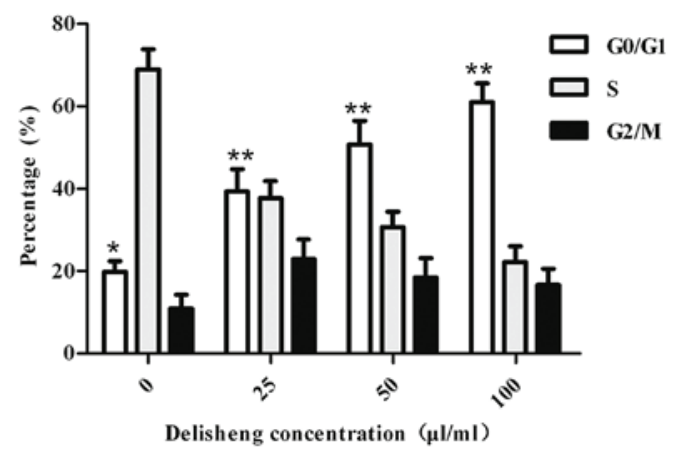

Figure 2. Effect of Delisheng on the cell cycle distribution of Hep3B cells. (A) Cell cycle distribution of Hep3B cells treated with 25,50 and $100 \mu 1 / \mathrm{ml}$ Delisheng for 24 h. (B) Graph represents quantitative data of cell cycle distribution. Data summarized as the mean + standard deviation from 3 independent experiments ( $\mathrm{P}<0.05$ and ${ }^{* *} \mathrm{P}<0.01$ for all treatments vs. untreated control). 
Table III. Delisheng-induced apoptosis in Hep3B and HL-7702 cell lines.

Early apoptosis rate, $\%^{\mathrm{a}}$

\begin{tabular}{lcccc}
\cline { 2 - 4 } Cells & Delisheng, $0 \mu \mathrm{l} / \mathrm{ml}$ & Delisheng, $25 \mu 1 / \mathrm{ml}$ & Delisheng, $50 \mu 1 / \mathrm{ml}$ & Delisheng, $100 \mu 1 / \mathrm{ml}$ \\
\hline Hep3B & $2.77 \pm 0.98^{\mathrm{b}}$ & $21.93 \pm 4.45^{\mathrm{b}}$ & $26.29 \pm 4.24^{\mathrm{b}}$ & $33.02 \pm 3.09^{\mathrm{b}}$ \\
HL-7702 & $2.15 \pm 1.44^{\mathrm{c}}$ & $6.26 \pm 3.12^{\mathrm{c}}$ & $8.52 \pm 2.55^{\mathrm{c}}$ & $15.84 \pm 2.67^{\mathrm{c}}$ \\
\hline
\end{tabular}

${ }^{\mathrm{a}} \mathrm{AnnexinV}(+) /$ propidium iodide (-) cells; ${ }^{\mathrm{b}} \mathrm{P}<0.05$, compared with the control cells. ${ }^{\mathrm{c}} \mathrm{P}<0.05$, compared with the control cells. Data are presented as the mean \pm standard deviation.

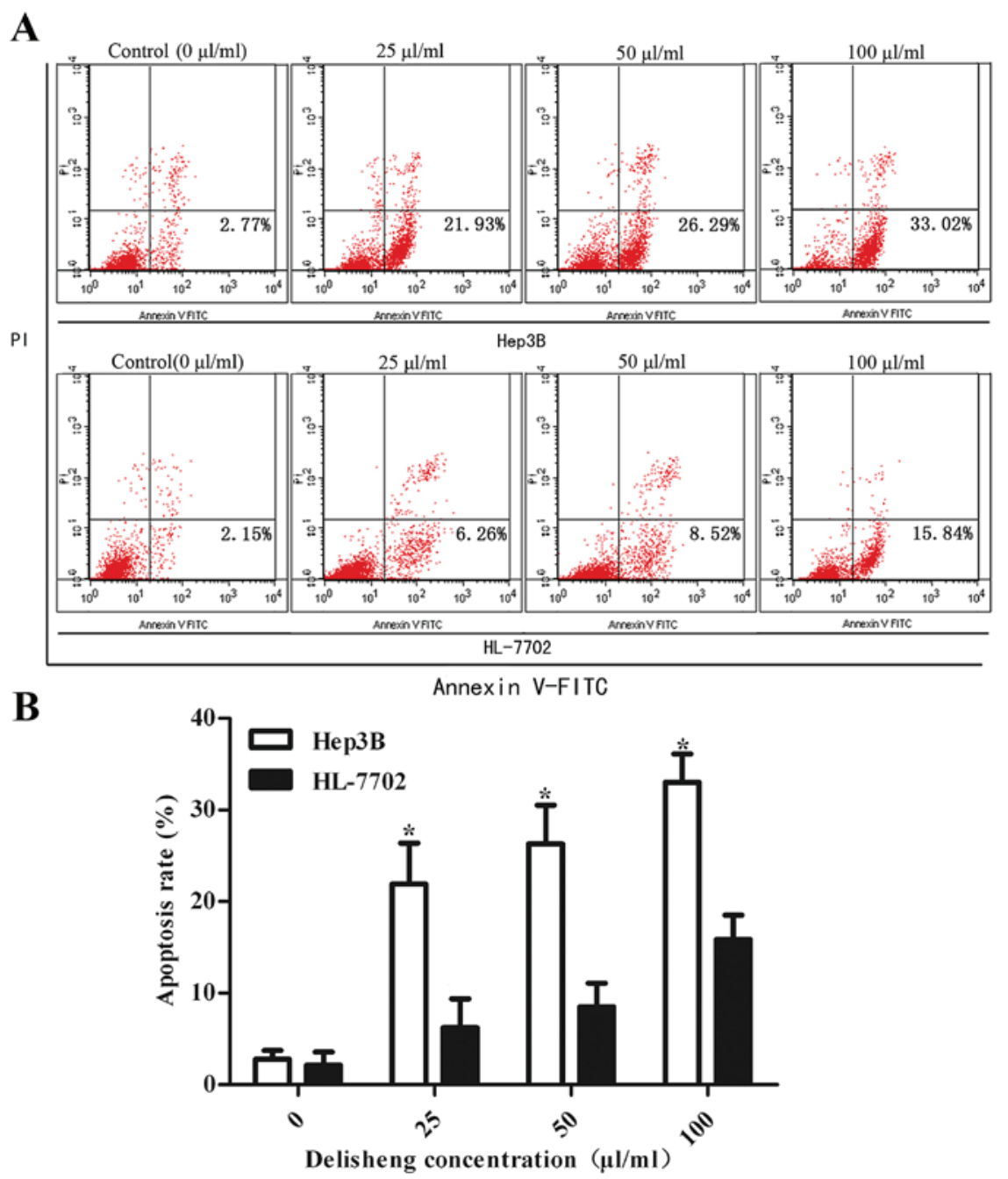

Figure 3. Effects of Delisheng on apoptosis of Hep3B and HL-7702 cells. (A) Hep3B and HL-7702 cells were treated with 25, 50 and $100 \mu 1 / \mathrm{ml}$ Delisheng for $24 \mathrm{~h}$. (B) Graph represents the flow cytometric data. Data summarized as the mean \pm standard deviation from 3 independent experiments. PI, propidium iodide; FITC, fluorescein isothiocyanate. ${ }^{*} \mathrm{P}<0.05$ vs. the control (HL-7702 cells).

radioimmunoprecipitation cell lysis buffer containing protease and phosphatase inhibitors (Xi'an Wolsen Biotechnology Co. Ltd., Xi'an, China). Protein concentrations in the cell extracts were determined using the BCA Protein Assay reagents (Pierce; Thermo Fisher Scientific, Inc.), according to the manufacturer's protocol. Each protein sample $(30 \mu \mathrm{g})$ was subject to $15 \%$ SDS-PAGE and transferred onto polyvinylidene difluoride membranes (Merck KGaA, Darmstadt, Germany), blocked with $8 \%$ non-fat milk for $2 \mathrm{~h}$ at RT. The membranes were labeled with primary antibodies overnight at $4^{\circ} \mathrm{C}$. Subsequently, blots were probed with horseradish peroxidase-conjugated secondary anti-rabbit IgG antibodies (1:5,000; cat. no., sc-2004; Santa Cruz Biotechnology, Inc., Dallas, TX, USA) at RT for $1 \mathrm{~h}$. The primary antibodies VEGF (cat. no., ab46154), OPN (cat. no., ab8448), ES (cat. no., ab64569) at dilutions of $1: 1,000$ and $\beta$-actin (cat. no., ab8227; 1:5,000) were purchased from Abcam (Cambridge, UK). For the quantification of protein levels, films were scanned and analyzed using 
Table IV. Expression of VEGF, OPN and ES in Hep3B cell lines treated with Delisheng.

Mean grey value

\begin{tabular}{lcccc}
\cline { 2 - 5 } Protein & Delisheng, $0 \mu \mathrm{l} / \mathrm{ml}$ & Delisheng, $25 \mu \mathrm{l} / \mathrm{ml}$ & Delisheng, $50 \mu 1 / \mathrm{ml}$ & Delisheng, $100 \mu 1 / \mathrm{ml}$ \\
\hline VEGF & $180.26 \pm 5.43^{\mathrm{a}}$ & $192.36 \pm 5.78^{\mathrm{a}}$ & $201.98 \pm 6.54^{\mathrm{a}}$ & $218.51 \pm 8.27^{\mathrm{a}}$ \\
OPN & $186.34 \pm 6.11^{\mathrm{b}}$ & $197.96 \pm 7.45^{\mathrm{b}}$ & $206.64 \pm 4.83^{\mathrm{b}}$ & $229.37 \pm 7.62^{\mathrm{b}}$ \\
ES & $145.56 \pm 7.52^{\mathrm{c}}$ & $132.31 \pm 4.16^{\mathrm{c}}$ & $120.15 \pm 4.25^{\mathrm{c}}$ & $107.69 \pm 4.31^{\mathrm{c}}$ \\
\hline
\end{tabular}

${ }^{a} \mathrm{P}<0.05$, compared with the control cells. ${ }^{\mathrm{b}} \mathrm{P}<0.05$, compared with the control cells. ${ }^{\mathrm{c}} \mathrm{P}<0.05$, compared with the control cells. VEGF, vascular endothelial growth factor; OPN, osteopontin; ES, endostatin.

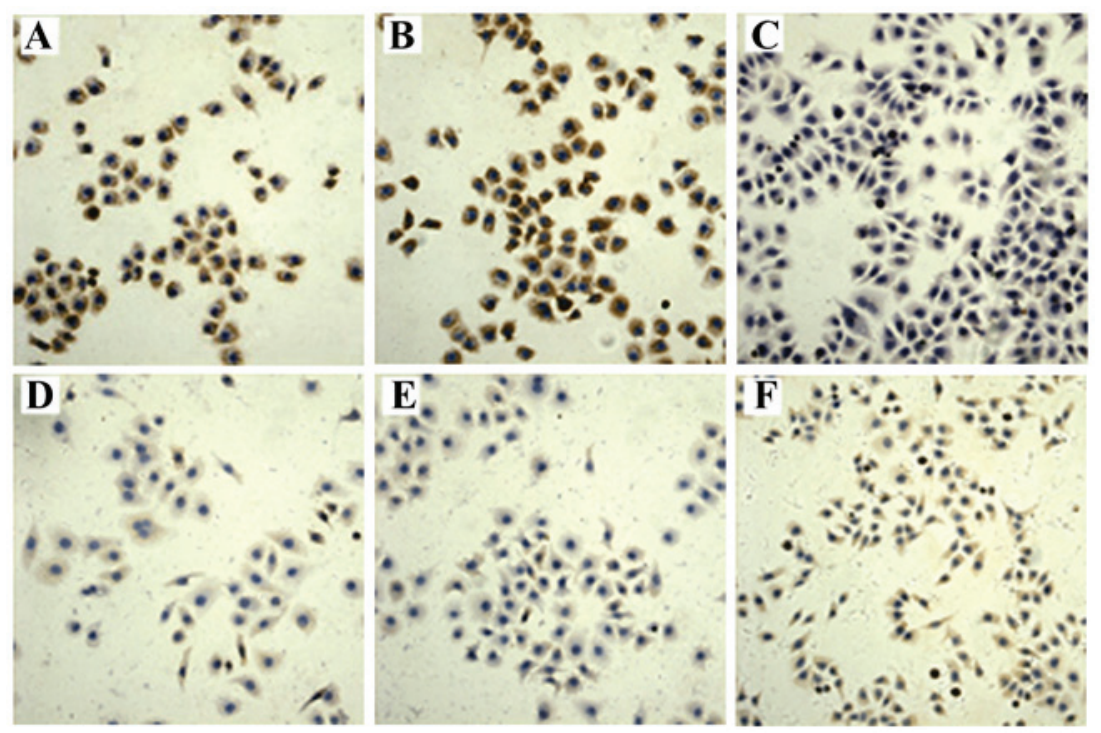

Figure 4. Immunocytochemistry analysis of Hep3B cells (magnification, x200). (A) VEGF, (B) OPN and (C) ES staining in Hep3B cells for $48 \mathrm{~h}$ without Delisheng treatment. (D) VEGF, (E) OPN and (F) ES staining in Hep3B cells treated with $25 \mu \mathrm{l} / \mathrm{ml}$ Delisheng for $48 \mathrm{~h}$. Results are representative of 4 identical experiments. VEGF, vascular endothelial growth factor; OPN, osteopontin; ES, endostatin.
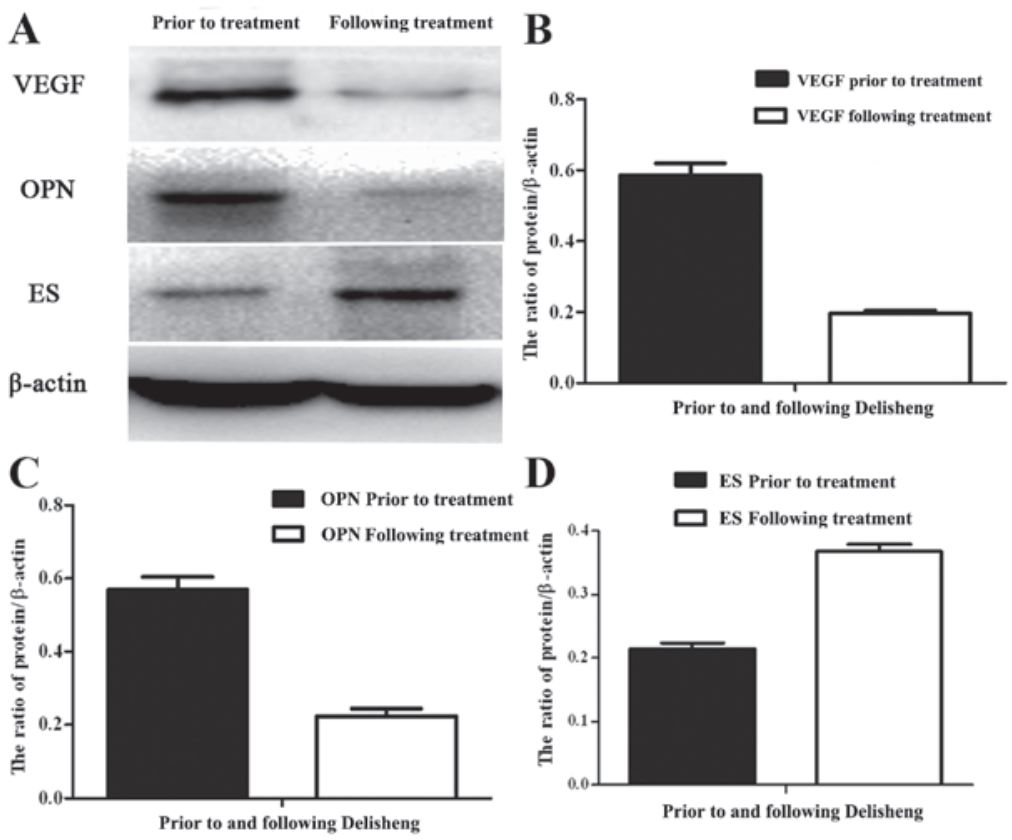

Figure 5. VEGF, OPN and ES are involved in Hep3B cells treated with Delisheng. (A) Cells treated with 25, 50 and $100 \mu 1 / \mathrm{ml}$ Delisheng for $48 \mathrm{~h}$, and subjected to western blot analysis of VEFG, OPN and ES expression. Graphs represent the quantitative data of the western blot analyses of (B) VEGF, (C) OPN and (D) ES. Results are representative of 4 identical experiments. VEGF, vascular endothelial growth factor; OPN, osteopontin; ES, endostatin. 
Labworks 4.0 software (World BioHazTec Corporation, NM, USA).

Statistical analysis. All results were presented as the mean \pm standard deviation. Statistical analysis was performed by one-way analysis of variance followed by Tukey's post hoc test. Student's t-test and Spearman's rank test using SPSS v.19.0 (IBM Corp., Armonk, NY, USA). P<0.05 was considered to indicate a statistically significant difference.

\section{Results}

Antiproliferative activity of Delisheng on Hep3B and $H L-7702$ cells. The cytotoxic effects of Delisheng were measured by MTT assay. Based on Table I and Fig. 1, exposure of these cells to Delisheng at the indicated concentrations for 24-72 $\mathrm{h}$ periods exhibited growth inhibition effects of Hep3B in a time- and dose-dependent manner. Compared to Hep3B cells, HL-7702 cells were less sensitive to the antiproliferative effects of Delisheng (Table I).

Effects of Delisheng on the cell cycles of Hep $3 B$ cells. To determine the mechanism underlying the antiproliferative activity of Delisheng on Hep3B cells, cell cycles were tested by flow cytometric analysis. As demonstrated in Table II and Fig. 2, in Hep3B cells treated with 25, 50 and $100 \mu \mathrm{l} / \mathrm{ml}$ Delisheng, $\mathrm{G}_{0} / \mathrm{G}_{1}$ cell cycle arrest was observed. In addition, the results indicated the cells exhibited $\mathrm{G}_{0} / \mathrm{G}_{1}$ phase arrest in a concentration-dependent manner.

Delisheng induces apoptosis. To additionally determine the potential mechanism of the anticancer effects of Delisheng, cell apoptosis was measured by flow cytometry. As indicated by Fig. 3 and Table III, following treatment with 25, 50 and $100 \mu \mathrm{l} / \mathrm{ml}$ Delisheng at $24 \mathrm{~h}$, the apoptotic rates of Hep3B cells were $21.93 \pm 0.98,26.29 \pm 4.45$ and $33.02 \pm 3.09 \%$, respectively $(\mathrm{P}<0.05$ vs. untreated cells). The HL-7702 cells, which exhibited apoptotic rates of $6.26 \pm 3.12,8.52 \pm 2.55$ and $15.84 \pm 2.67 \%$, at 25,50 and $100 \mu \mathrm{l} / \mathrm{ml}$ Delisheng at $24 \mathrm{~h}$, respectively, and Delisheng-untreated Hep3B cells did not demonstrate evidence of apoptosis.

VEGF, OPN and ES are involved in Hep3B cells treated with Delisheng. Immunocytochemistry analysis demonstrated that the levels of VEGF, OPN and ES expression were observed in the cytoplasm of Hep3B cells. Fig. 4 indicates that Delisheng treatment increased VEGF and OPN and decreased ES protein expression levels $(\mathrm{P}<0.05)$. As observed in Fig. 5 and Table IV, western blotting analysis additionally confirmed the results. Furthermore, the Spearman's rank correlation analysis indicated that OPN was positively correlated with VEGF expression ( $\mathrm{r}=0.58, \mathrm{P}=0.011)$. However, $\mathrm{ES}$ was negatively correlated with VEGF $(r=0.57, P=0.009)$ and OPN expression $(\mathrm{r}=0.69, \mathrm{P}=0.025)$.

\section{Discussion}

Delisheng has demonstrated antitumor activities for specific types of cancer (17-19). Ginsenoside Rg3 (Rg3), one of the bioactive extracts from Delisheng, exerts an antiproliferation effect on prostate cancer cells (20). For $\sim 80 \%$ of patients with prostate cancer, Delisheng treatment alone may alleviate symptom of weakness, improve quality of life and decrease prostate specific antigen (PSA) levels (21). Our previous studies suggested that Delisheng exhibited cytotoxic activities and triggered time- and concentration-dependent apoptosis in HepG2 cells by activating the mitochondria-mediated and death receptor-mediated apoptotic pathways $(11,17)$.

Cell cycle progression serves a pivotal role in maintaining homeostasis in healthy tissues. Numerous anticancer agents arrest the cell cycle and then induce cell death (22-25). In the present study, the results demonstrated that the antiproliferative and proapoptotic activities of Delisheng may be attributed to $\mathrm{G}_{0} / \mathrm{G}_{1}$ cell cycle arrest. Delisheng induced antiproliferation and apoptosis in Hep3B cells, but exhibited no significant effect on HL-7702 cells. These data suggested that Delisheng may exhibit less toxicity in normal liver cells compared with in HCC cells.

VEGF and OPN may induce tumor angiogenesis, which is crucial for the malignant process of cancer (26-29). VEGF exerts multiple functions including endothelial cell mitogenesis and migration, remodeling of the extracellular matrix, increased vascular permeability and maintenance of the survival of novel blood vessel formation (30). A number of tumors highly express VEGF, which is correlated with tumor invasiveness, vascular density, metastasis/recurrence and unfavorable prognosis (31-33). OPN is a phosphorylated acidic glycoprotein which functions in cell attachment, and is also a cytokine that signals through $\alpha v \beta 3$-integrin and cluster of differentiation 44. Binding of OPN to these cell surface receptors stimulates cell adhesion, proliferation and migration (34). Previous studies indicated that the expression of VEGF was associated with OPN expression, and that they may serve as prognostic factors for non-small-cell lung cancer (27). The data of the present study demonstrated that Delisheng downregulated VEGF and OPN expression in Hep3B cell ina concentration-dependent manner. ES is a proteolytic cleavage product of type XVIII collagen, and interacts with multiple cell-surface molecules (35). It inhibits endothelial cells proliferation, migration/invasion and increases tumor cells apoptosis (36). Furthermore, ES suppressed the expression of VEGF, matrix metalloproteinases, fibroblast growth factor and cell adhesion molecule $(37,38)$. Certain previous studies revealed that tumor growth was inhibited in transgenic mice overproducing ES $(39,40)$. Based on the results of the present study, the upregulation of ES and downregulation of VEGF and OPN may be responsible for the anticancer effect of Delisheng on Hep3B cells.

Taken together, the results of the present study provide novel evidence that Delisheng induces antiproliferation and apoptosis in Hep3B cells, at least in part through downregulating VEGF and OPN and upregulating ES, which may assist in the validation of the clinical application of Delisheng. Additional studies investigating the underlying anticancer mechanisms and for its potential as a novel anticancer therapeutic in $\mathrm{HCC}$ are required.

\section{Acknowledgements}

The present study was supported by grants from the National Natural Science Foundation of China (grant no. 81372581). 


\section{References}

1. Siegel RL, Miller KD and Jemal A: Cancer statistics, 2015. CA Cancer J Clin 65: 5-29, 2015.

2. Buell J: Hepatoma Research: The beginning of a new forum. Hepatoma Res 1: 1-5, 2015.

3. El-Serag HB, Marrero JA, Rudolph L and Reddy KR: Diagnosis and treatment of hepatocellular carcinoma. Gastroenterology 134: 1752-1763, 2008.

4. Choi KJ, Baik IH, Ye SK and Lee YH: Molecular targeted therapy for hepatocellular carcinoma: Present status and future directions. Biol Pharm Bull 38: 986-991, 2015.

5. Wu T, Jiao M, Jing L, Wang MC, Sun HF, Li Q, Bai YY, Wei YC, Nan KJ and Guo H: Prognostic value of Notch-1 expression in hepatocellular carcinoma: A meta-analysis. Onco Targets Ther 8: 3105-3114, 2015.

6. Wang X, Wang N, Cheung F, Lao L, Li C and Feng Y: Chinese medicines for prevention and treatment of human hepatocellular carcinoma: Current progress on pharmacological actions and mechanisms. J Integr Med 13: 142-164, 2015.

7. Zhai XF, Qiao CX, Liu Q, Chen Z and Ling CQ: Quality assessment of clinical research on liver cancer treated by intra-arterial infusion of Chinese medicine. Chin J Integr Med 20: 870-875, 2014.

8. Wu P, Dugoua JJ, Eyawo O and Mills EJ: Traditional Chinese Medicines in the treatment of hepatocellular cancers: A systematic review and meta-analysis. J Exp Clin Cancer Res 28: 112, 2009.

9. Qi F, Li A, Inagaki Y, Gao J, Li J, Kokudo N, Li XK and Tang W: Chinese herbal medicines as adjuvant treatment during chemoor radio-therapy for cancer. Biosci Trends 4: 297-307, 2010.

10. Qi F, Li A, Zhao L, Xu H, Inagaki Y, Wang D, Cui X, Gao B, Kokudo N, Nakata M and Tang W: Cinobufacini, an aqueous extract from Bufo bufo gargarizans Cantor, induces apoptosis through a mitochondria-mediated pathway in human hepatocellular carcinoma cells. J Ethnopharmacol 128: 654-661, 2010.

11. Wang SH, Wang YC, Nie YL, Hai YN, Sun HF, Yuan ZL and Nan KJ: Antiproliferative activity of the chinese medicinal compound, delisheng, compared with $\operatorname{Rg} 3$ and gemcitabine in HepG2 Cells. Indian J Pharm Sci 75: 578-584, 2013.

12. Sredni B: Immunomodulating tellurium compounds as anti-cancer agents. Semin Cancer Biol 22: 60-69, 2012.

13. Hanahan D and Folkman J: Patterns and emerging mechanisms of the angiogenic switch during tumorigenesis. Cell 86: 353-364, 1996.

14. Raja R, Kale S, Thorat D, Soundararajan G, Lohite K, Mane A, Karnik S and Kundu GC: Hypoxia-driven osteopontin contributes to breast tumor growth through modulation of HIF1 $\alpha$-mediated VEGF-dependent angiogenesis. Oncogene 33. 2053-2064, 2014.

15. Bao Y, Feng WM, Tang CW, Zheng YY, Gong HB and Hou EG: Endostatin inhibits angiogenesis in hepatocellular carcinoma after transarterial chemoembolization. Hepato-gastroenterology 59: 1566-1568, 2012.

16. Gai P, Sun H, Wang G, Xu Q, Qi X, Zhang Z and Jiang L: miR-22 promotes apoptosis of osteosarcoma cells via inducing cell cycle arrest. Oncol Lett 13: 2354-2358, 2017.

17. Lu CX, Nan KJ, Nie YL, Hai YN and Jiao M: Delisheng, a Chinese medicinal compound, exerts anti-proliferative and pro-apoptotic effects on HepG2 cells through extrinsic and intrinsic pathways. Mol Biol Rep 37: 3407-3412, 2010.

18. Dong XL, Gong Y, Chen ZZ and Wang YJ: Delisheng injection (), a Chinese medicinal compound, enhanced the effect of cis-platinum on lung carcinoma cell line PGCL3. Chin J Integr Med 20: 286-291, 2014.

19. Zhao D, Liu XJ, Xie Q, Huang ZP, Zou BX and Ge YB: Intensity-modulated radiation combined with Delisheng injection for naspharyngeal carcinoma. Nan Fang Yi Ke Da Xue Xue Bao 26: 874-875, 2006 (In Chinese).

20. Pan XY, Guo H, Han J, Hao F, An Y, Xu Y, Xiaokaiti Y, Pan Y and Li XJ: Ginsenoside Rg3 attenuates cell migration via inhibition of aquaporin 1 expression in PC-3M prostate cancer cells. Eur J Pharmacol 683: 27-34, 2012.

21. Zhang SW, Zhou SY, Shao JC and Qu XW: Primary research on Chinese medicine treatment of androgen-independent prostate cancer. Chin J Integr Med 15: 168-169, 2009.

22. Lee $\mathrm{HH}$, Lee $\mathrm{S}$, Lee $\mathrm{K}$, Shin $\mathrm{YS}$, Kang $\mathrm{H}$ and $\mathrm{Cho} \mathrm{H}$ : Anti-cancer effect of Cordyceps militaris in human colorectal carcinoma RKO cells via cell cycle arrest and mitochondrial apoptosis. Daru 23: 35, 2015.
23. Tsui KC, Chiang TH, Wang JS, Lin LJ, Chao WC, Chen BH and Lu JF: Flavonoids from Gynostemma pentaphyllum exhibit differential induction of cell cycle arrest in $\mathrm{H} 460$ and A549 cancer cells. Molecules 19: 17663-17681, 2014.

24. Lee YS, Choi KM, Kim W, Jeon YS, Lee YM, Hong JT, Yun YP and Yoo HS: Hinokitiol inhibits cell growth through induction of S-phase arrest and apoptosis in human colon cancer cells and suppresses tumor growth in a mouse xenograft experiment. J Nat Prod 76: 2195-2202, 2013.

25. Feng R and Dong L: Knockdown of microRNA-127 reverses adriamycin resistance via cell cycle arrest and apoptosis sensitization in adriamycin-resistant human glioma cells. Int J Clin Exp Pathol 8: 6107-6116, 2015.

26. Zeng Z, Huang WD, Gao Q, Su ML, Yang YF, Liu ZC and Zhu BH: Arnebin-1 promotes angiogenesis by inducing eNOS, VEGF and HIF-1 $\alpha$ expression through the PI3K-dependent pathway. Int J Mol Med 36: 685-697, 2015.

27. Lin Q, Guo L, Lin G, Chen Z, Chen T, Lin J, Zhang B and $\mathrm{Gu}$ X: Clinical and prognostic significance of OPN and VEGF expression in patients with non-small-cell lung cancer. Cancer Epidemiol 39: 539-544, 2015.

28. Ramchandani D and Weber GF: Interactions between osteopontin and vascular endothelial growth factor: Implications for cancer. Biochim Biophys Acta 1855: 202-222, 2015.

29. Gong X, Tong Q, Chen Z, Zhang Y, Xu C and Jin Z: Microvascular density and vascular endothelial growth factor and osteopontin expression during the implantation window in a controlled ovarian hyperstimulation rat model. Exp Ther Med 9: 773-779, 2015

30. Ferrara N: Vascular endothelial growth factor: Basic science and clinical progress. Endocr Rev 25: 581-611, 2004.

31. Chen P, Zhu J, Liu DY, Li HY, Xu N and Hou M: Over-expression of survivin and VEGF in small-cell lung cancer may predict the poorer prognosis. Med Oncol 31: 775, 2014.

32. Li C, Li R, Song H, Wang D, Feng T, Yu X, Zhao Y, Liu J, Yu X, Wang Y and Geng J: Significance of AEG-1 expression in correlation with VEGF, microvessel density and clinicopathological characteristics in triple-negative breast cancer. J Surg Oncol 103: 184-192, 2011.

33. Li J, Li L, Li Z, Gong G, Chen P, Liu H, Wang J, Liu Y and Wu X: The role of miR-205 in the VEGF-mediated promotion of human ovarian cancer cell invasion. Gynecol Oncol 137: 125-133, 2015.

34. Chen J, Zhu C, He Z, Geng M, Li G, Tao X and Zhang F: Association of OPN overexpression with tumor stage, differentiation, metastasis and tumor progression in human laryngeal squamous cell carcinoma. Int J Clin Exp Med 8: 7116-7124, 2015.

35. Gao P, Gao YJ and Liang HL: Effect of NF- $\kappa$ B inhibitor PDTC on VEGF and endostatin expression of mice with Lewis lung cancer. Asian Pac J Trop Med 8: 220-224, 2015.

36. Hu Y, Hu MM, Shi GL, Han Y and Li BL: Imbalance between vascular endothelial growth factor and endostatin correlates with the prognosis of operable non-small cell lung cancer. Eur J Surg Oncol 40: 1136-1142, 2014.

37. Lim J, Duong T, Lee G, Seong BL, El-Rifai W, Ruley HE and Jo D: The effect of intracellular protein delivery on the anti-tumor activity of recombinant human endostatin. Biomaterials 34 : 6261-6271, 2013

38. Xu W, Ye P, Li Z, Shi J, Wang W and Yao K: Endostar, a recently introduced recombinant human endostatin, inhibits proliferation and migration through regulating growth factors, adhesion factors and inflammatory mediators in choroid-retinal endothelial cells. Mol Biol (Mosk) 44: 664-670, 2010.

39. Sund M, Hamano Y, Sugimoto H, Sudhakar A, Soubasakos M, Yerramalla U, Benjamin LE, Lawler J, Kieran M, Shah A and Kalluri R: Function of endogenous inhibitors of angiogenesis as endothelium-specific tumor suppressors. Proc Natl Acad Sci USA 102: 2934-2939, 2005.

40. Lee SH, Jeung IC, Park TW, Lee K, Lee DG, Cho YL, Lee TS, Na HJ, Park YJ, Lee HG, et al: Extension of the in vivo half-life of endostatin and its improved anti-tumor activities upon fusion to a humanized antibody against tumor-associated glycoprotein 72 in a mouse model of human colorectal carcinoma. Oncotarget 6: 7182-7194, 2015. 